\title{
Implications of COVID-19 on the Global Mining Sector
}

ISSN: 2578-0255

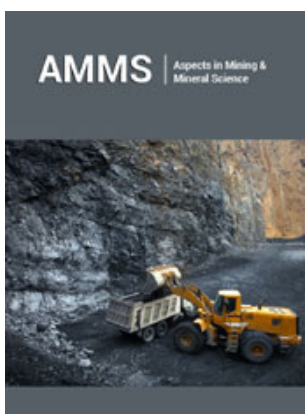

*Corresponding author: Vlado Vivoda, Senior Lecturer in Strategic Studies, Deakin University and Honorary Fellow, Centre for Social Responsibility in Mining, Sustainable Minerals Institute, University of Queensland, Australia

Submission: 阱 May 12, 2020

Published: 侮 May 19, 2020

Volume 4 - Issue 5

How to cite this article: Vlado Vivoda. Implications of COVID-19 on the Global Mining Sector. Aspects Min Miner Sci. 4(5) AMMS.000600. 2020.

DOI: 10.31031/AMMS.2020.04.000600

Copyright@ Vlado Vivoda, This article is distributed under the terms of the Creative Commons Attribution 4.0 International License, which permits unrestricted use and redistribution provided that the original author and source are credited.

\section{Vlado Vivoda*}

Senior Lecturer in Strategic Studies, Honorary Fellow, Centre for Social Responsibility in Mining, Sustainable Minerals Institute, Australia

\section{Mining is Cyclical}

A cyclical industry is sensitive to the business cycle. Revenues are generally higher in periods of economic growth and are lower in periods of economic downturn. Mineral price cycles mean that mining companies' expenditure on exploration and investment can vary considerably. Price fluctuations also have a significant effect on fiscal revenues, exchange rates and employment levels of countries rich in metals and minerals. The reasons for price cycles lie in the high volatility of demand for metal and mineral commodities and inflexible supply responsiveness. Demand for metals and mineral commodities is highly sensitive to changes in the rate of economic growth, partly because of the characteristics of the economic sectors in which these commodities are used. These economic sectors, which include construction and the production of capital goods and consumer durables, require large long-term investments, and tend to be more volatile than general economic activity. Demand for metals and mineral commodities is also sensitive to manufacturers' stockholding. As economies grow, manufacturers tend to build up stocks in anticipation of increased production, adding to the demand for metals and minerals. When economies retract, manufacturers often reduce their stocks, thus suppressing demand for metal and mineral commodities.

Supply of metals and mineral commodities is highly inflexible. This inflexibility arises from the fact that metals and mineral commodities are produced at capital-intensive, largescale operations, where producers run their operations at close to full capacity. Even when faced with lower demand and prices, suppliers often continue to produce at maximum capacity, further weakening prices. The capital-intensive nature of mineral production is a major additional cause of supply inflexibility. It is common for a major new mining operation to take a decade from conception to production. Perhaps unsurprisingly, supply tends to be slow in responding to short-term fluctuations in demand. Significant supply adjustments, both at times of cyclical downswings and upswings, tend to be slow and take several years to manifest.

\section{Challenges Caused by COVID-19}

When the pandemic first arose in late 2019 and more consequently in 2020, the world was going through economic stagnation and significant consumer downturn. Most economists believed a recession, though one which would not be too severe, was coming. As a result of the fast spread of the pandemic, economies across the world have had to initiate lockdowns to curb the spread of the virus. With new social distancing measures taken in response to the pandemic, a "Great Lockdown" occurred of the world economy. The global lockdown triggered the simultaneous collapse of various industries and consumerism, which placed major pressure on banks and employment. The COVID-19 pandemic shuttered industrial activity, first in China in February, and in most of the world by mid-March. This, in turn, caused a stock market crash and thereafter, a deep global recession. Global markets, banks, businesses, and governments are facing a crisis not seen since the Great Depression of 1929. The abrupt halt of commercial activity threatens to impose economic pain so profound and enduring in every region of the world at once that recovery could take years. 
The pandemic has affected the mining industry in a variety of ways. Mining operations have been impacted through isolated outbreaks, government mandated shutdowns and the lower demand for many commodities. The primary impact on the sector has been a dramatic drop in demand due to a collapse in industrial production and construction. The metals and minerals sector saw a suddenly harsh economic outlook push most commodity prices, with a notable exception of gold, to multi-year lows by the end of the first quarter of 2020. Dramatic falls in prices have been mirrored by collapses in the shares of many of the large mining multinationals. In addition to impacts through lower prices and share values, mining activity itself has been hit directly by COVID-19, with operations suspended across various countries. For example, in Mongolia, Rio Tinto was forced to suspend non-essential operations. Quarantine in Peru and South Africa has meant that mining companies have had to put a halt to operations. Mine workers in Burkina Faso, Chile and Ghana have tested positive for COVID-19. Under commercial of government pressure, numerous mines in Canada, New Zealand and Zambia had shut-down production, bringing additional future capital costs from re-opening mine sites. Nickel has lost one-third of production, due to high reliance on the Philippines, where numerous mines have been closed. Resource-rich economies and many mining operations are facing the additional pressure due to the deep global recession, which is coming on the heels of the pandemic.

The long-term implications for the industry will depend on the duration of the lockdown, and the economic, political and social conditions that emerge in its aftermath. There are indications that the downturn could be far more punishing and long-lasting than initially feared-potentially stretching into 2021, and even beyondas governments intensify restrictions on business to stop the spread of the pandemic, and as fear of the virus reconfigures the very concept of public space, impeding consumer-led economic growth. Regardless of the exact nature and extent of long-term global economic implications, a deep global recession has thrown the global mining industry into a rapid cyclical downswing. However, unlike in previous downturns, as demand for many metals and mineral commodities is falling, in some cases supplies may be dropping at a faster rate. This implies that some mineral and metal prices, such as gold, could rise during this economic downturn. The impetus for industry stakeholders is to keep track on how the sector needs to respond to the broader supply-demand disruptions caused by the pandemic. The immediate future of numerous mining operations around the world is uncertain. Numerous mines will enter care-and-maintenance, associated with greater risk of mine abandonment. The Democratic Republic of the Congo (DRC) Mining minister recently warned against the social and economic impact of mine closures during the COVID-19 pandemic. Closure of various major mine operations worldwide will be brought forward, particularly in the thermal coal sector. Because coal power generation is more expensive than gas, wind or solar, thermal coal is the first to suffer when power demand is down. Lower demand translates to an excess inventory, which will force numerous coal mines into early retirement. Struggling miners may be unable to implement mine closure and rehabilitations plans as initially envisioned or ensure safe operation of tailings facilities. It is highly likely that there will be mounting pressure on governments to step in to protect mining communities and the surrounding environment from adverse effects of early closure, and to prevent catastrophic tailings dam failures. In addition, the downturn is likely to significantly delay mining companies' roll out of larger scale autonomous operations, as for the foreseeable future it may be considered politically or socially unpalatable to reduce workforce numbers materially.

\section{Long-Term Opportunities}

The scale and impact of the COVID-19 is unprecedented in history of mining. The situation is dynamic and is evolving rapidly. While each day may bring new challenges to mining companies, it is also important to recognize and act on opportunities. For example, as COVID-19 plays out, mining companies can demonstrate that the value they bring to governments and host communities extends well beyond the borders of the mine site. The crisis provides an opportunity for bringing key mining stakeholders closer together with the aim of ensuring continued operations under mutually agreed terms. At a time when much of the global energy industry is in crisis, wind and solar projects are having their moment in the sun. There is also likely to be a greater push for electric vehicles. Renewable energy is one of the few sectors that has managed to weather the devastating effects of COVID-19, with new deals and new records being struck, even while the rest of the world has been grappling with the pandemic. The renewables sector is forecast to be the only part of the global energy system that will grow in 2020 . This is promising for mining companies involved in the renewable energy and electric vehicle value chains, and otherwise in the supply of critical metals. The metals for which renewable energy and electric vehicle industry take a growing and/or significant share of end-use include aluminum, cobalt, copper, graphite, lead, lithium, indium, molybdenum, neodymium, nickel, silver, tellurium, vanadium, and zinc. The impetus will be on responsible sourcing of these metals through verified certification schemes.

For possible submissions Click below:

Submit Article 